\title{
A DECISION SUPPORT TOOL TO REDUCE POLLUTION ALONG ROSETTA BRANCH
}

\author{
Donia, Noha, S. ${ }^{(1)}$;El Saadi, A. M. ${ }^{(2)}$;Yousry, M. M. ${ }^{(3)}$ \\ and Awaad, Heba, K. $^{(3)}$
}

1) Environmental Studies and Researches Institute, Ain Shams University

2) Drainage Research Institute, 3) Nile Research Institute, National Water Research Center, The Ministry of Water Resources and Irrigation.

\begin{abstract}
The main objective of this paper is to study the variation of some water quality variables along Rosetta Branch, to study the impact of drains discharging their wastes directly on the water quality of the branch and to define the optimum scenario requires overcoming the serious problem of the pollution in the branch. Water samples were collected from the branch as well as from the outfall of the drains during January 2011, August 2011, January 2016, August 2016, and March 2017 and analyzed for physicochemical parameters according the standard procedures. The Results indicated that, there is a degradation in water quality along the area located downstream ElRahawy drain. This was reflected by low dissolved oxygen concentration that reaches to $0.07 \mathrm{mg} / \mathrm{l}$. As well as, the $\mathrm{BOD}$ value was also recorded high values of $110 \mathrm{mg} / \mathrm{l}$. These values were found 18 times higher than the allowable limits of law 48/year 1982 and its ministerial decree. It is worth to mention that, the area along Rosetta Branch comply with the permissible limits of the value of NH3 recommended by law 48 year 1982, except the area located downstream El-Rahawy and Sabal drains. Different scenarios are applied using Duflow model. The study concluded that, the water quality along Rosetta Branch has been significantly impacted with the drains especially El-Rahawy and Sabal, which consider the worst drains. The best scenario is the treatment of El-Rahawy drain with biological biofilm activated with aerator that improves the water quality along Rosetta Branch based on applying Duflow model.
\end{abstract}

Keywords: Wastewater, Rosetta Branch, Duflow model. 
J. Environ. Sci.

Institute of Environmental Studies and Research - Ain Shams University

\section{INTRODUCTION}

The water quality control of the drains discharging their wastes directly to Rosetta Branch is an important factor to mitigate the pollution levels along Rosetta Branch. (Abu-El-Ela, 1996) Is one of the first attempts to use one dimensional water quality models for study the impacts of wastewater discharges in the Nile. (Donia, 2005) Was built a Rosetta Branch waste load allocation model to define the total maximum daily loads for pollutants of concern especially to preserve aquatic life. Many loading scenarios were conducted. Based on the results of these scenarios, the total maximum daily loads were established for Rosetta Branch. Applications demonstrate that the developed model can be used by decision makers as a tool for quality management. (Mohsen, 2006) Conduct a study includes the determination of the environmental pollution levels in water and sediment of Damietta and Rosetta Nile branches and assessing the potential of Damietta sediment for amendment of agricultural land with respect to heavy metal mobilization. Moreover, different scenarios were applied using water quality model to mitigate the pollution along Rosetta branch. (Hossam El din, 2008) Study the determination of the environmental pollution levels in water and sediment of Rosetta branch. Moreover, different scenarios were applied using water quality model to reduce the pollution along Rosetta branch. This paper focus on the effect of the drains discharging their wastes directly to Rosetta Branch and how it has the principle role in the pollution of the Branch.

So the aim of this study is to specify the variation of some water quality variables along Rosetta Branch, to find the interaction between the drains 
discharging directly to Rosetta Branch and the pollution levels in the branch. As well as to apply a Duflow model on the branch to define the best scenarios require overcoming the serious problem of the pollution along the branch.

\section{MATERIALS AND METHODS}

Study Area: The Rosetta Branch flows downstream Delta Barrage to the north-west (about $225 \mathrm{Km}$ ). It is considered the main source of fresh water for the western side of the Nile Delta. It ends with Idfina Barrage which regulates the excess flow of the branch. Effluent samples from El-Rahawy, Sabal, South El-Tahrir, Zawyat El-Bahr, and Tala drains discharge their wastes on Rosetta Branch respectively were collected. As well as, five samples collected upstream drains, and the other five samples collected downstream drains along Rosetta branch during January 2011, August 2011, January 2016, August 2016, and March 2017 as shown in Table (1) and Figure (1). Water sampling was analyzed according to Standard Methods for Examination of Water and Wastewater (APHA, 2005). 
J. Environ. Sci.

Institute of Environmental Studies and Research - Ain Shams University

Table(1): The study survey locations and their codes

\begin{tabular}{|c|c|c|c|c|c|}
\hline Code & Drain & Upstream & $\mathbf{A T}$ & Downstream & $\begin{array}{c}\text { km from } \\
\text { Delta Barrage }\end{array}$ \\
\hline USR & \multirow{3}{*}{ El-Rahawy } & $\sqrt{1}$ & & & 8.50 \\
\hline RD & & & $\sqrt{ }$ & & 9.00 \\
\hline DSR & & & & $\sqrt{ }$ & 9.50 \\
\hline USS & \multirow{3}{*}{ Sabal } & $\sqrt{ }$ & & & 69.90 \\
\hline SD & & & $\sqrt{ }$ & & 70.40 \\
\hline DSS & & & & $\sqrt{ }$ & 70.90 \\
\hline USST & \multirow{3}{*}{ South Tahrir } & $\sqrt{ }$ & & & 84.50 \\
\hline STD & & & $\sqrt{ }$ & & 85.00 \\
\hline DSST & & & & $\sqrt{ }$ & 85.50 \\
\hline USZ & \multirow{3}{*}{$\begin{array}{l}\text { Zawyat } \\
\text { El-Bahr }\end{array}$} & $\sqrt{ }$ & & & 99.20 \\
\hline $\mathrm{ZD}$ & & & $\sqrt{ }$ & & 99.70 \\
\hline DSZ & & & & $\sqrt{ }$ & 100.20 \\
\hline UST & \multirow{3}{*}{ Tala } & $\sqrt{ }$ & & & 121.50 \\
\hline TD & & & $\sqrt{ }$ & & 122.00 \\
\hline DST & & & & $\sqrt{ }$ & 122.50 \\
\hline
\end{tabular}

Water Quality Model: The DUFLOW package Version 2.05 is used for the simulation model of Rosetta branch. It is based on the one dimensional partial differential equation that describes non-stationary flow in open channels (Abbott, 1979); (Dronkers, 1964). The water quality model of the DUFLOW package is based upon the one-dimensional advertive-dispersive transport (Bureau ICIM, 1995). Seven scenarios were applied by using this model including:

- Scenario (1): El-Rahawy removal.

- Scenario (2): 50\% load reduction El-Rahawy.

- Scenario (3): Wetland treatment.

- Scenario (4): Biofilm activated with aerator. 
- Scenario (5): Increase the flow into double.

- Scenario (6): The wetland treatment and double flow.

- Scenario (7): Biofilm activated with aerator and double flow.

\section{RESULTS AND DISCUSSION}

This part is devoted to study the impact of wastewaters from pollution sources on the water quality of Rosetta Branch.

Dissolved Oxygen (DO): The results of DO concentration in water at monitored sites along Rosetta Branch varied between $0.07 \mathrm{mg} / \mathrm{l}$ at the area located downstream El-Rahawy drain and $8.5 \mathrm{mg} / \mathrm{l}$ at the area upstream ElRahawy drain that we consider as a reference point, as shown in Figure (2), and Figure (3). El-Rahawy drain, Sabal drain, South El-Tahrir drain, Zawyat El-Bahr drain, and Tala drain recorded values respectively of $1.37 \mathrm{mg} / 1,0.13$ $\mathrm{mg} / \mathrm{l}, 8.38 \mathrm{mg} / \mathrm{l}, 4.14 \mathrm{mg} / \mathrm{l}, 0.93 \mathrm{mg} / \mathrm{l}$. The DO levels fell sharply in the area located directly downstream El-Rahawy drain. It is worth mentioning that, DO concentrations in wastewater discharging from all drains violate the value recommended by law 48 year 1982 and its ministerial decree no.92 for year 2013 (not less than $5 \mathrm{mg} / \mathrm{l}$ ) except South El-Tahrir drain.

This depletion of dissolved oxygen in the Rosetta Branch may be attributed to microbial decomposition of the organic matter that is discharging directly from the drain. Based on the value of DO recommended by law 48 year 1982 and its ministerial decree no.92 for year 2013 (not less than $6 \mathrm{mg} / \mathrm{l}$ ) it was found that, the area downstream El-Rahawy drain didn't comply with the permissible limits. Results indicated degradation in water quality along the area downstream El-Rahawy drain. This was reflected by a dissolved 
oxygen concentration of about $0.07 \mathrm{mg} / \mathrm{l}$. At the same locations, BOD value was $110 \mathrm{mg} / \mathrm{l}$ (18 times higher than the allowable limits).

Ammonia: Ammonia concentration along Rosetta Branch showed that they ranged between $0.01 \mathrm{mg} / \mathrm{l}$ at upstream Zawyat El-Bahr drain, downstream Zawyat El-Bahr drain and $24 \mathrm{mg} / \mathrm{l}$ at downstream El-Rahawy drain as shown in Figure (4), and Figure (5). However, El-Rahawy drain recorded value of $24.75 \mathrm{mg} / \mathrm{l}$, Sabal drain recorded value of $26.75 \mathrm{mg} / \mathrm{l}$, South El-Tahrir drain recorded value of $0.18 \mathrm{mg} / \mathrm{l}$, Zawyat El-Bahr drain recorded value of 0.12 $\mathrm{mg} / \mathrm{l}$, and Tala drain recorded value of $0.39 \mathrm{mg} / \mathrm{l}$. The reference point at US El-Rahawy drain recorded value of $0.05 \mathrm{mg} / \mathrm{l}$. Some sites along Rosetta Branch showed high concentrations of ammonia (NH3), which are toxic to aquatic life (fish mortality), and also it is used as an indication of organic pollution caused from domestic sewage, industrial waste and fertilizer runoff. From Figure (4) and based on the value of NH3 recommended by law 48 year 1982 and its ministerial decree no.92 for year 2013 (not more than 0.5 $\mathrm{mg} / \mathrm{l})$ it was found that, the area along Rosetta Branch comply with the permissible limits, except the area located downstream El-Rahawy and Sabal drains. Ammonia is much more toxic in alkaline water than acid because free ammonia $(\mathrm{NH} 3)$ at high $\mathrm{pH}$ values $(\mathrm{pH}>8.5)$ is more toxic to aquatic biota than when it is in the ionized form (NH4+) (DWAF, 1996).

Ammonia concentration in unpolluted waters usually is found to be less than $0.2 \mathrm{mg} / \mathrm{l}$ as Nitrogen (Chapman, 1992). 
Biological Oxygen Demand: The data of BOD concentrations along Rosetta Branch ranged between $1 \mathrm{mg} / \mathrm{l}$ at upstream El-Rahawy drain that we consider as a reference point and $110 \mathrm{mg} / \mathrm{l}$ at downstream El-Rahawy drain as shown in Figure (6), and Figure (7). El-Rahawy drain recorded value of $110 \mathrm{mg} / \mathrm{l}$, Sabal drain recorded value of $50 \mathrm{mg} / \mathrm{l}$, South El-Tahrir drain recorded value of $10 \mathrm{mg} / \mathrm{l}$, Zawyat El-Bahr drain recorded value of $24 \mathrm{mg} / \mathrm{l}$, and Tala drain recorded value of $20 \mathrm{mg} / \mathrm{l}$. Rosetta Branch suffers from organic pollution and depletion in oxygen concentration which in turn lead to fish mortality along the branch especially during winter closure due to the low dilution capacity of Rosetta Branch. The low concentrations of BOD in the reference point and most sites along Rosetta Branch due to high capacity of its water to assimilate the organic material in the presence of high levels of DO. From Figure (6) and based on the value of BOD recommended by law 48 year 1982 and its ministerial decree no.92 for year 2013 (not more than $6 \mathrm{mg} / \mathrm{l}$ ) it was found that, the area along Rosetta Branch violate the permissible limits, except the area located upstream El-Rahawy drain that we consider as a reference point. However, the BOD concentrations in wastewater discharging from all drains comply the value recommended by law 48 year 1982 and its ministerial decree no.92 for year 2013 (not more than $30 \mathrm{mg} / \mathrm{l}$ ), except El-Rahawy and Sabal drains as shown in Figure (7). It is worth mentioning that, unpolluted waters typically have BOD values of $2 \mathrm{mg} / \mathrm{l}$ or less, whereas those receiving wastewater may have values up to $10 \mathrm{mg} / \mathrm{l}$ or more, particularly near to the point of wastewater discharge (Chapman, 1992). 
Comparing the results of BOD along Rosetta Branch with the standard limits recommended by law 48 year 1982 (6 mg/l) it was found that, all recorded values along Rosetta Branch violate the standard limits of law 48 except at the reference point.

Duflow model: Based on the above results, it is recommended that applying a Duflow model on the branch to define the optimum scenario required for overcoming the serious problem of the pollution along the branch.

The water flow and quality of Rosetta Branch could be successfully simulated using the water quality model DUFLOW.

Once the model has been successfully calibrated and verified, its predictive ability should be further considered by sensitivity analysis. This involves a study of the extent to which the models accuracy in prediction is affected by changes in the inputs to the model. The effect of each pollution source separately is analyzed. This was done by calculating the change in the BOD and NH3 concentrations in Rosetta Branch due to each pollution source and comparing this effect with the present status as shown in Figures (8-11). Scenario (1): The removal of El-Rahawy drain leads to reduce the concentration of BOD and ammonia by about $68 \%$ and $48 \%$ respectively in January, and $26 \%$ and $54.7 \%$ respectively in August and the DO concentration increased.

Scenario (2): $50 \%$ load reduction of El-Rahawy leads to reduce the concentration of BOD and ammonia by about $34 \%$ and $24.6 \%$ respectively in January, and $13 \%$ and $27 \%$ respectively in August. 
Scenario (3): Applying the wetland treatment leads to reduce the concentration of BOD and ammonia by about $39 \%$ and $24.6 \%$ respectively in January, and 14\% and 27\% respectively in August.

Scenario (4): Applying biofilm activated with aerator leads to reduce the concentration of BOD and ammonia by about $62.4 \%$ and $46 \%$ respectively in January, and $23.7 \%$ and $52 \%$ respectively in August.

Scenario (5): The increasing of the flow into double, $15.01 \mathrm{~mm} 3 /$ day in January 2016 and $39.964 \mathrm{~mm} 3 /$ day in August 2016. This scenario leads to reduce the concentration of $\mathrm{BOD}$ and ammonia by about $26 \%$ and $31 \%$ respectively in January, and 4\% and 23\% respectively in August.

Scenario (6): The wetland treatment and double flow leads to reduce the concentration of BOD and ammonia by about $50.6 \%$ and $46 \%$ respectively in January, and $13.4 \%$ and $40 \%$ respectively in August.

Scenario (7): Biofilm activated with aerator and double flow leads to reduce the concentration of BOD and ammonia by about $65 \%$ and $59 \%$ respectively in January, and $18.9 \%$ and $55 \%$ respectively in August.

It is worth mention that, the application of biofilm could serve as an ideal process and could make a great wastewater treatment; however, this calls for detailed pilot scale and field studies (Shohreh Azizi, 2013).

\section{CONCLUSIONS AND RECOMMENDATIONS}

The study concluded that, the water quality of the Rosetta Branch has been significantly impacts as evidence by the low dissolved oxygen concentration downstream El-Rahawy drain in the western bank. The results of $50 \%$ reduction (scenario 2) in El-Rahawy drain are close to the results of 
wetland treatment (scenario 3). However, the results of removal El-Rahawy drain (scenario 1) are close the results of biological biofilm activated with aerator (scenario 4). The best scenarios are removal El-Rahawy drain, treatment with biological biofilm activated with aerator, and biological biofilm activated with aerator scenario and double flow to the branch. The study recommended to apply the biological biofilm activated with aerator scenario, because it is easy to apply comparing with other scenarios.

\section{FIGURES}

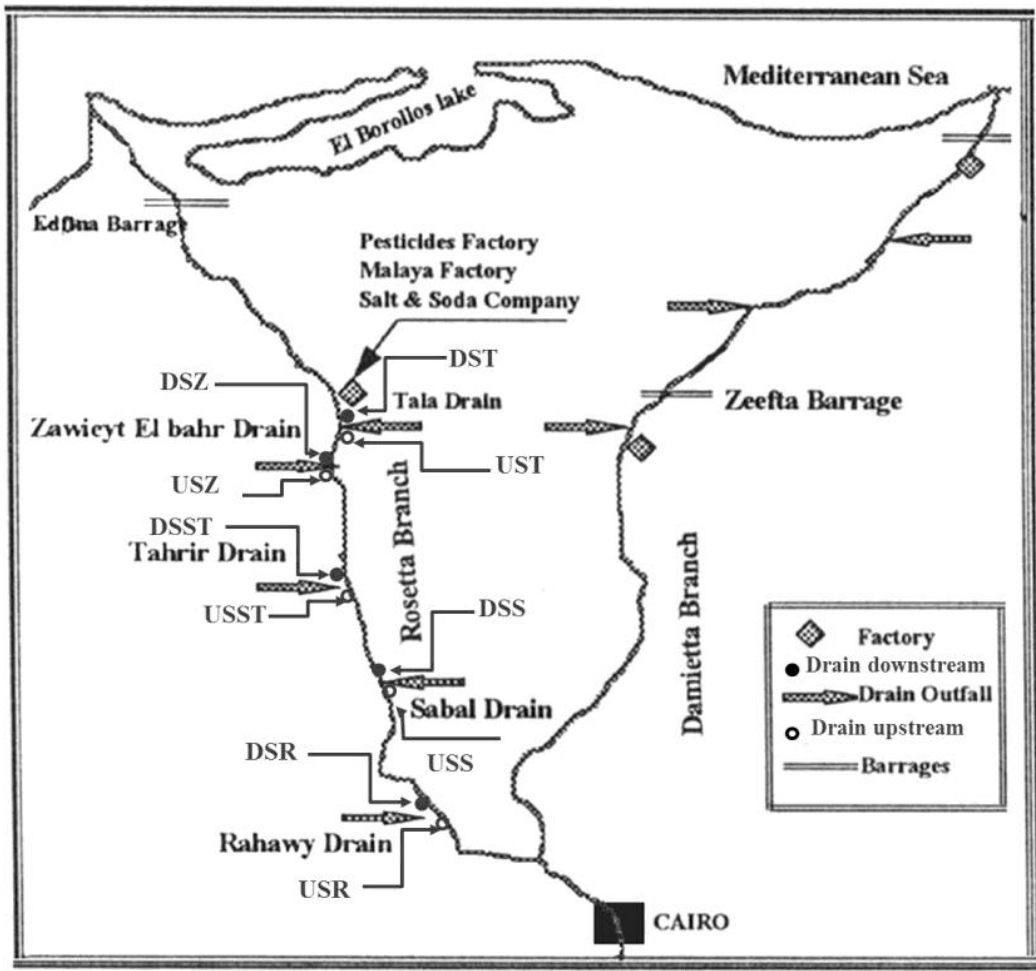

Figure(1): Map of sampling locations (Drains and Rosetta branch) 


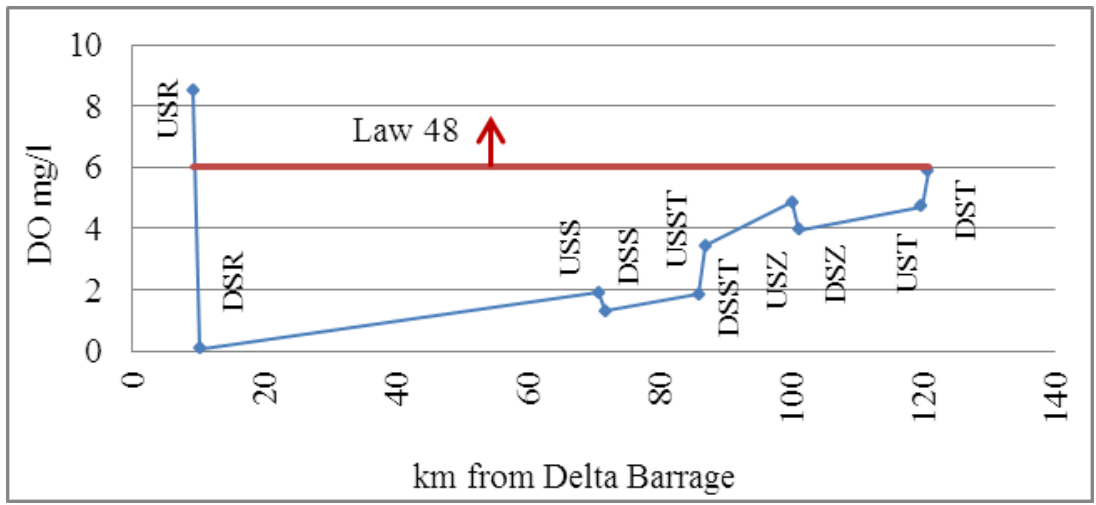

Figure(2): DO concentrations along Rosetta Branch

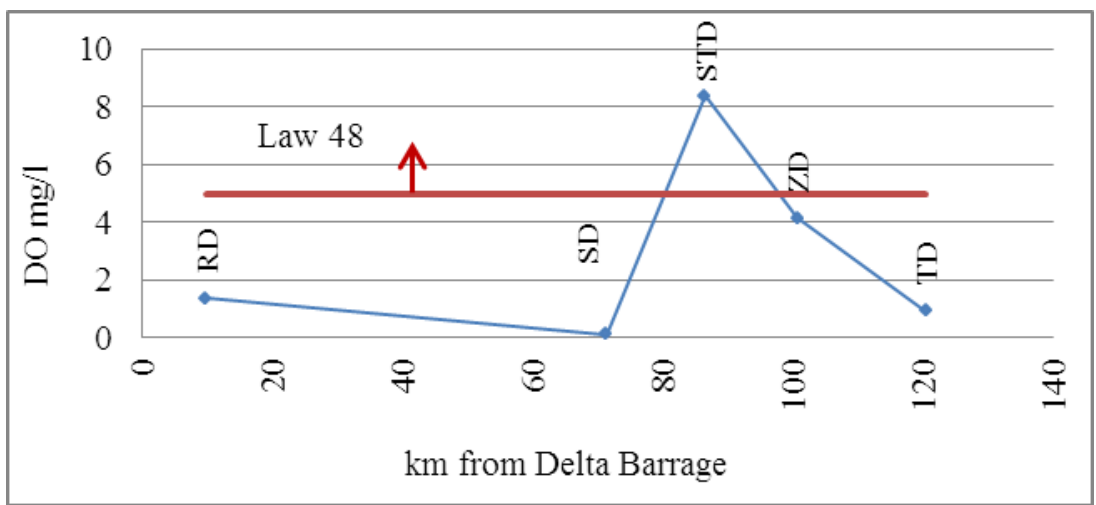

Figure(3): DO concentrations at Rosetta Branch drains

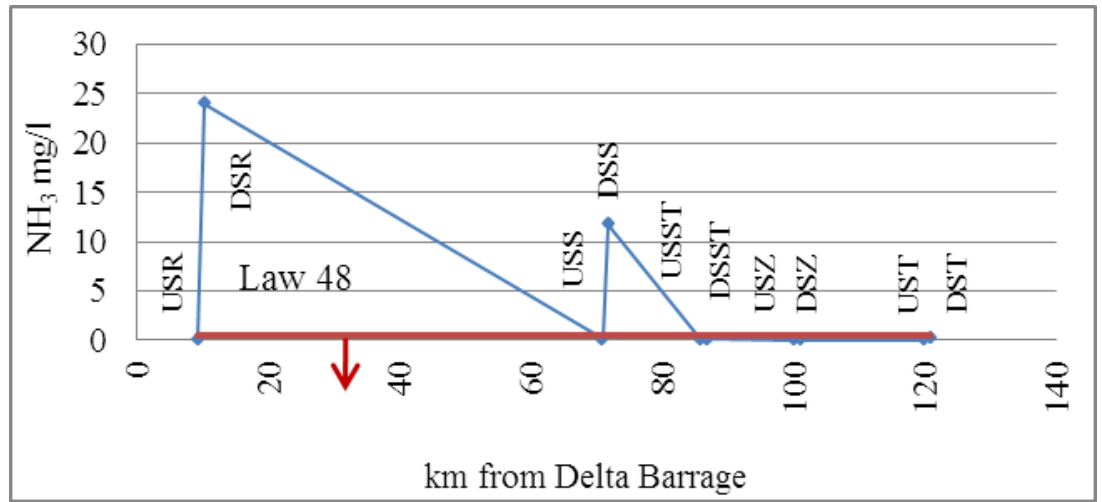

Figure(4): NH3 concentrations along Rosetta Branch

Vol. 40, No.2, Dec. 2017 
J. Environ. Sci.

Institute of Environmental Studies and Research - Ain Shams University

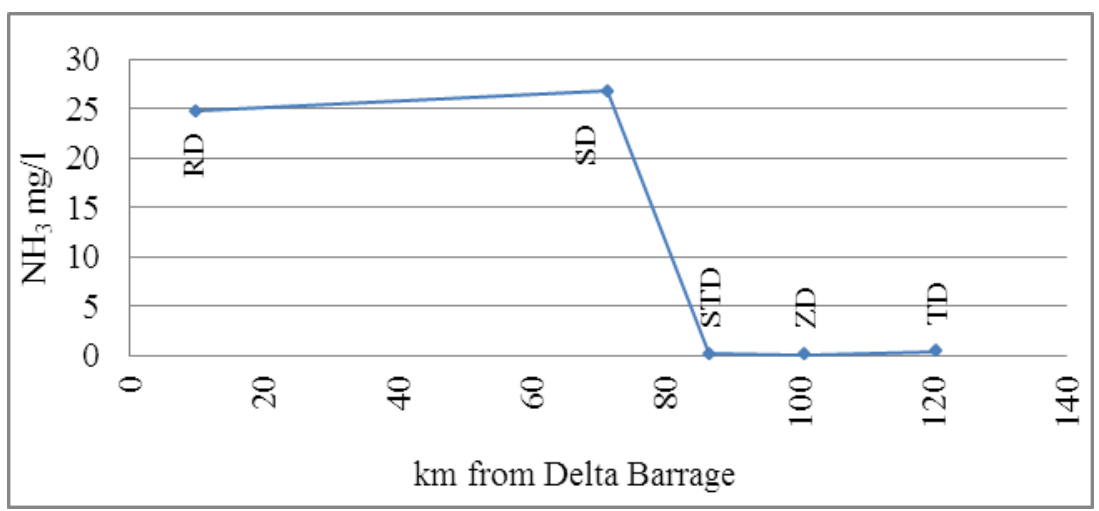

Figure (5): NH3 concentrations at Rosetta Branch drains

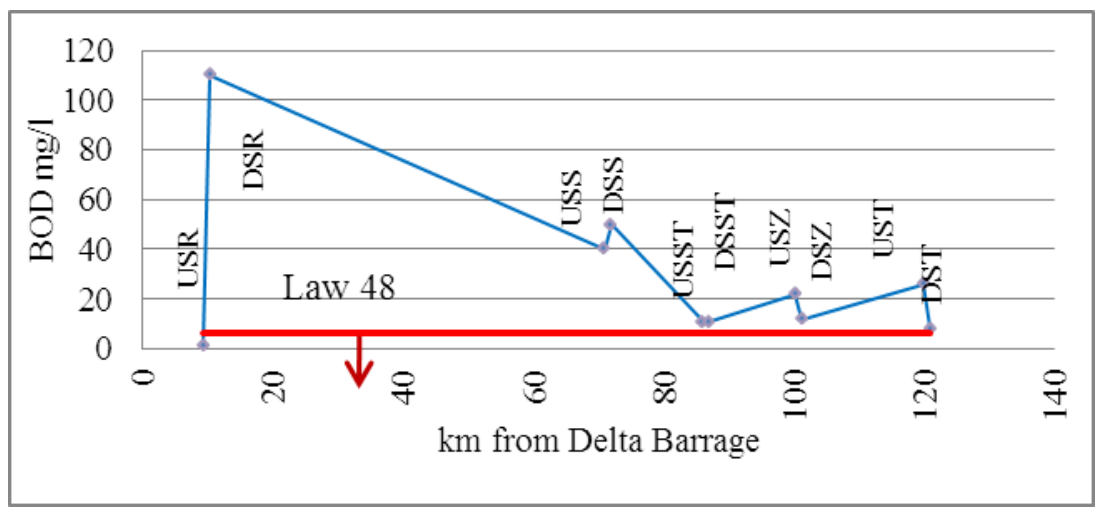

Figure (6): BOD concentrations along Rosetta Branch

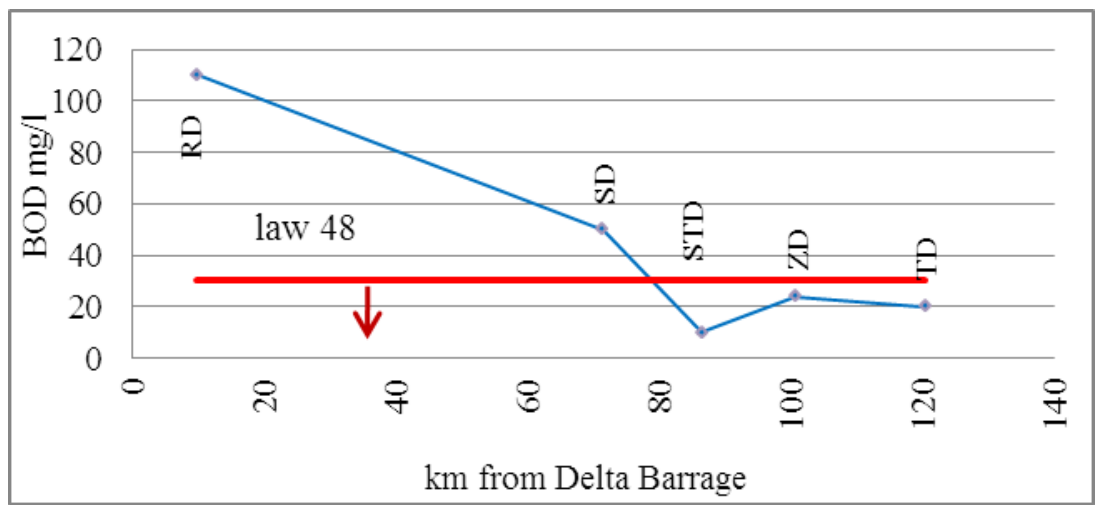

Figure(7): BOD concentrations at Rosetta Branch drains 


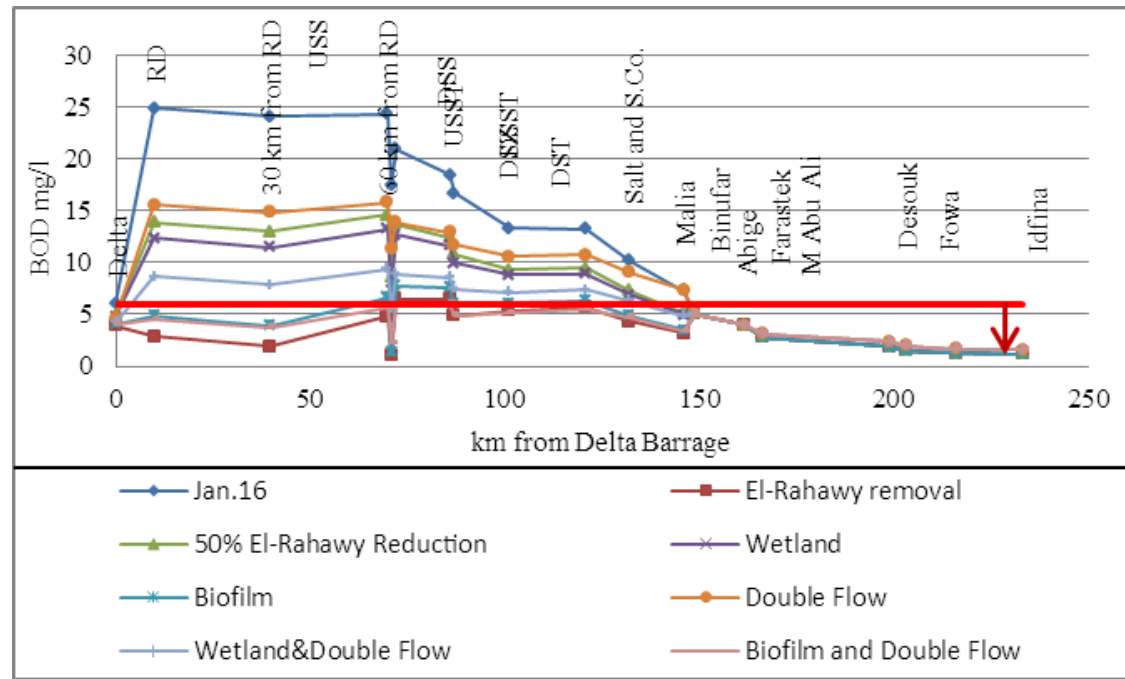

Figure(8): BOD Scenarios concentrations at Rosetta Branch in January

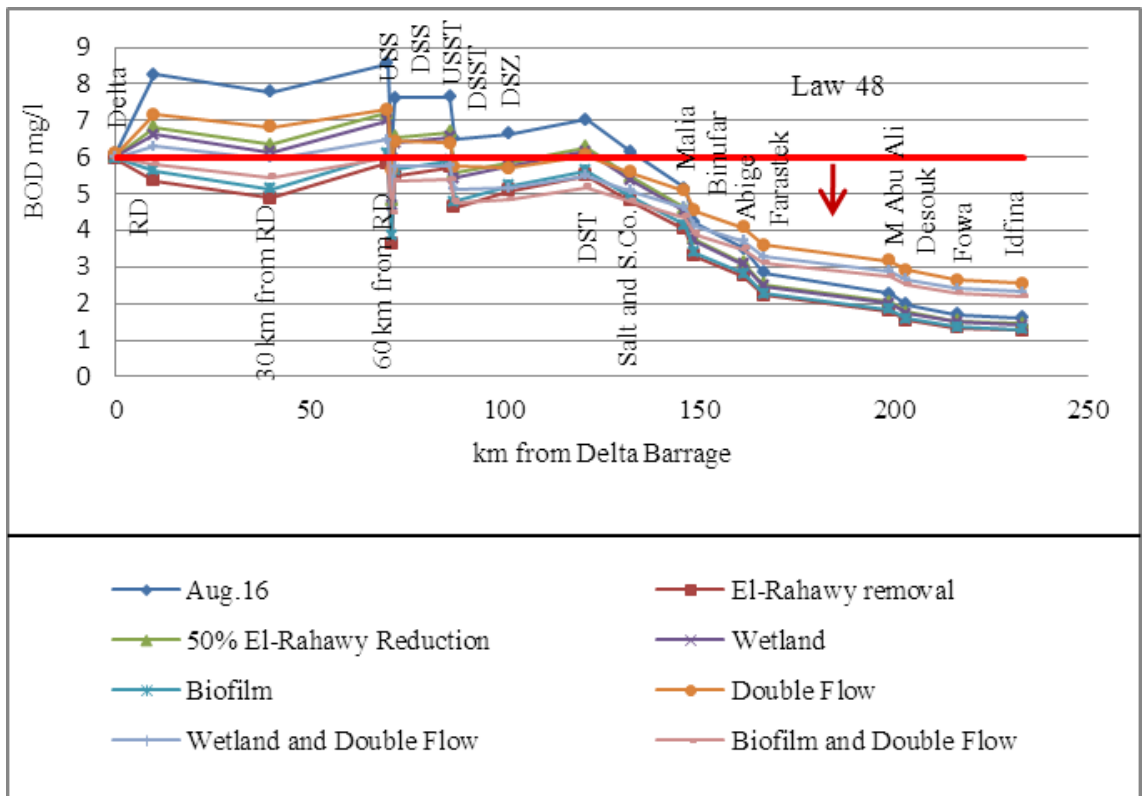

Figure(9): BOD Scenarios concentrations at Rosetta Branch in August 
J. Environ. Sci.

Institute of Environmental Studies and Research - Ain Shams University

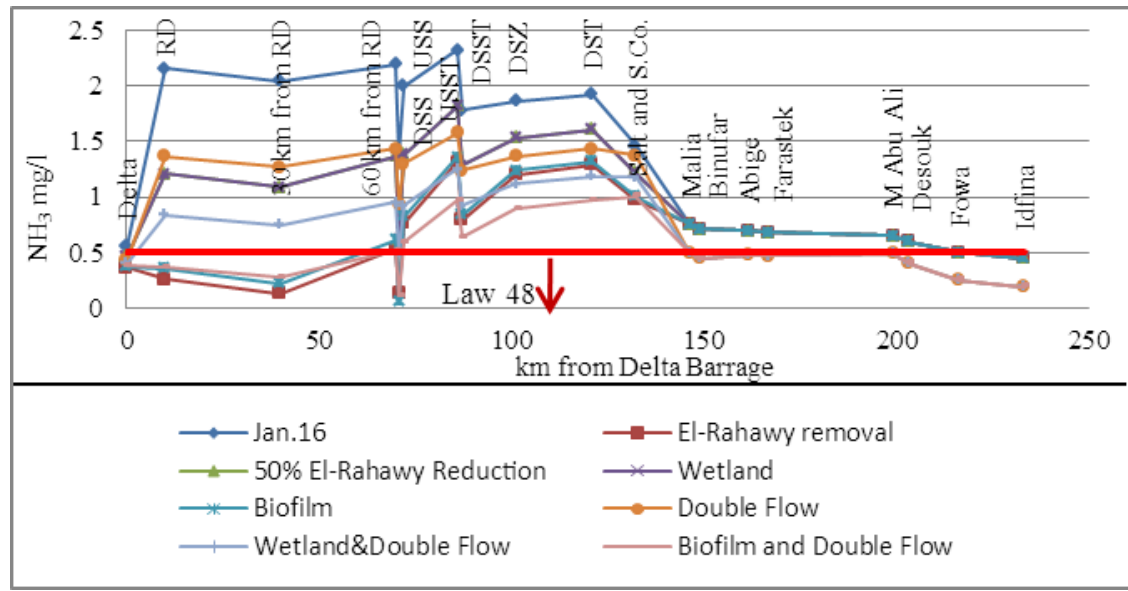

Figure(10): NH3 Scenarios concentrations at Rosetta Branch in January

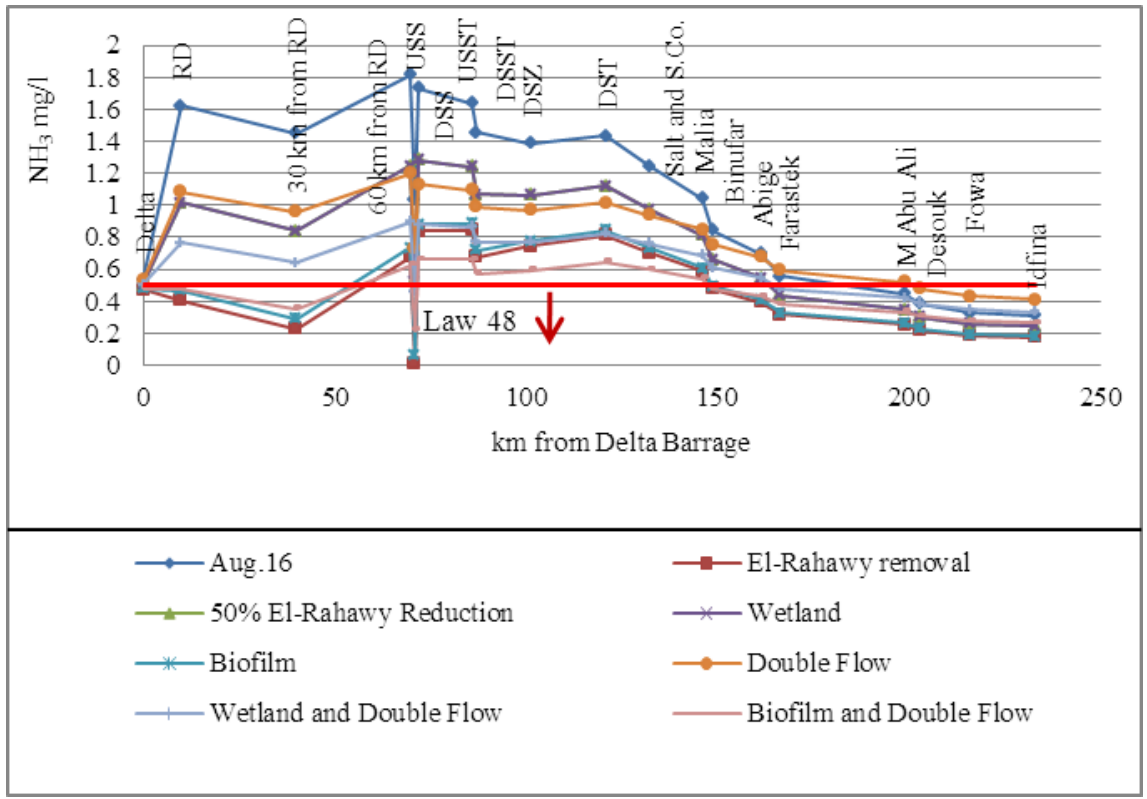

Figure(11): NH3 Scenarios concentrations at Rosetta Branch in August 


\section{REFERENCES}

Abbott, M.B. (1979) Computational Hydraulics. London: Pitman, pp. 55-89.

Abu-El-Ela, S., Shehata, S., and El-Bahrawy, A. (1996) "Impact of Wastwater Discharges on Phytoplanktonic Structure of the Nile River." The Scientific Bulletin of the Faculty of Engineering, Ain Shams University, 31, No (1), p. 148-167.

APHA. (2005) Standard Methods for the Examination of Water and Wastewater. 21th Edition. Washington, D.C.: American Public Health Association.

Bureau ICIM, Rijswijk. (1995) DUFLOW - a Micro Computer Package for the Simulation of One Dimensional Unsteady Flow and Water Quality in Open Channel Systems. Netherlands.

Chapman, D., In. (1992)Water quality assessments 1st ed. London, and New York: Chapman and Hall.

Donia, Noha. (2005) "ROSETTA BRANCH WASTE LOAD ALLOCATION MODEL." Ninth International Water Technology Conference, IWTC9 . Sharm El-Sheikh, Egypt, p. 277-288.

Dronkers, J.J. (1964) Tidal computations in rivers and tidal waters. Amsterdam: North Holland Publishing Co.

DWAF. (1996) "South African water quality guidelines" 7: aquatic ecosystems 1st edn. Department of water affairs \& forestry, Pretoria.

Hossam El din, Mohamed Mohamed. (2008) “Assessment of Environmental Pollution Sources and its Impact on Rosetta Branch Water quality", Science Department, Environmental Studies and Researches Institute, Ain Shams University, MSc thesis.

Mohsen, Mohamed Mahmoud Yousry. (2006) "STUDIES ON WATER, SEDIMENTS AND POLLUTION INTERACTION THROUGH ROSSETTA AND DAMIETTA NILE BRANCHES" Faculty of Science, Zagazig University, $\mathrm{PhD}$ thesis. 
Shohreh Azizi, Alireza Valipour,and Thami Sithebe. (2013) "Evaluation of Different Wastewater Treatment Processes and Development of a Modified Attached Growth Bioreactor as a Decentralized Approach for Small Communities."

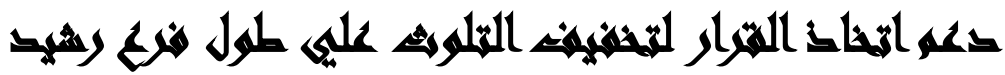

\section{[}

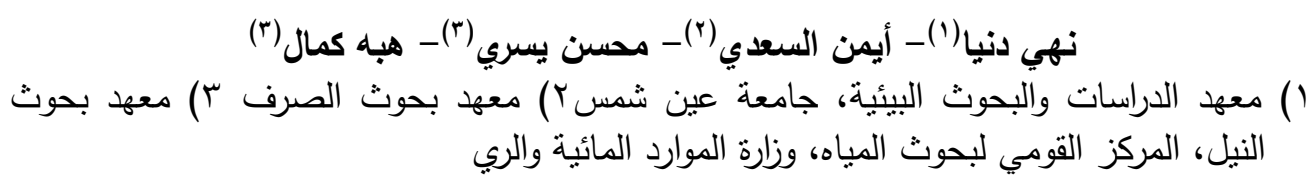

\section{المستخلصن}

الهدف الرئيسي من هذا البحث هو دراسة تباين بعض متغيرات نوعية المياه على طول فرع رشيد ودراسة تأثير المصارف التي تصرف مخلفاتها مباشرة على نوعية المياه للفرع وتحديد السيناريو

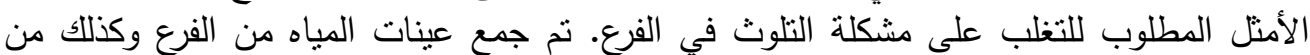

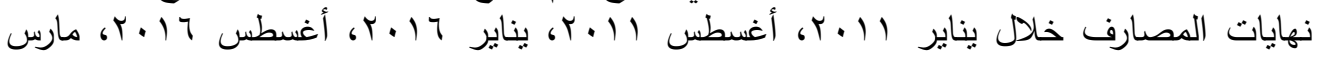

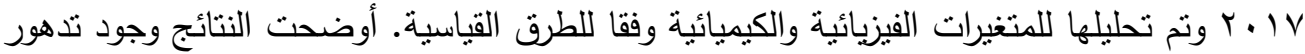

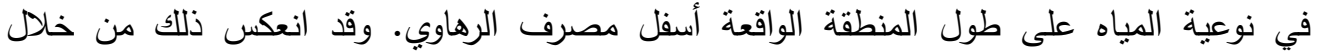

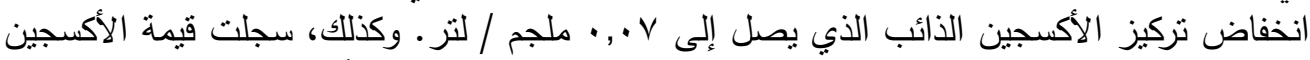

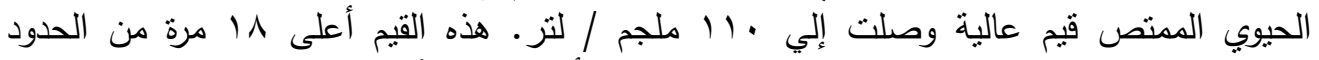

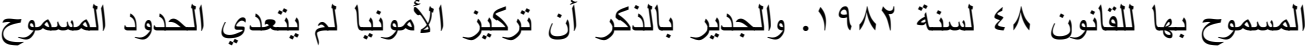

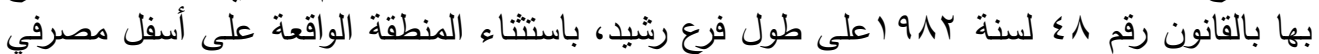

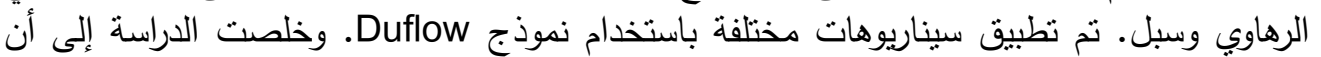

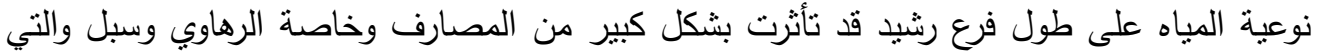

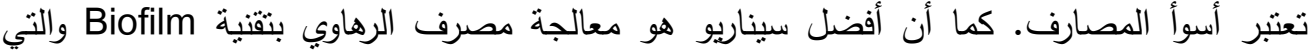

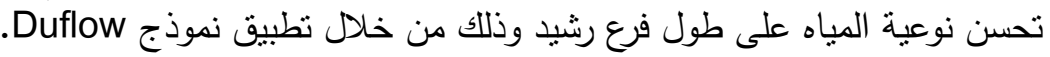

